Meta

Journal des traducteurs

Translators' Journal

\title{
Socio-Cultural Characteristics Found in Russian-Korean Translation of Metaphoric Expressions
}

\section{Hye-Seung Lee}

Volume 51, numéro 2, juin 2006

Théories et pratiques de la traduction et de l'interprétation en Corée Theories and Practices of Translation and Interpretation in Korea

URI : https://id.erudit.org/iderudit/013262ar

DOI : https://doi.org/10.7202/013262ar

Aller au sommaire du numéro

Éditeur(s)

Les Presses de l'Université de Montréal

ISSN

0026-0452 (imprimé)

1492-1421 (numérique)

Découvrir la revue

Citer cet article

Lee, H.-S. (2006). Socio-Cultural Characteristics Found in Russian-Korean Translation of Metaphoric Expressions. Meta, 51(2), 368-377.

https://doi.org/10.7202/013262ar
Résumé de l'article

Cet article a pour but de réfléchir sur les stratégies utilisées par les traducteurs lorsqu'ils traduisent les métaphores, le facteur qui reflète le mieux la différence socioculturelle entre deux pays. Nous nous sommes particulièrement intéressé à la traduction en coréen de textes écrits en russe. Le résultat de notre analyse montre qu'une bonne connaissance de la différence socioculturelle de la Russie et de la Corée est un élément primordial pour assurer la qualité de la traduction et pour surmonter les limites de la traduction coréen-russe, relativement récente en Corée. 


\title{
Socio-Cultural Characteristics Found in Russian- Korean Translation of Metaphoric Expressions
}

\author{
HYE-SEUNG LEE \\ Suwon University, Suwon, Korea \\ lena1997@hanmail.net
}

\section{RÉSUMÉ}

Cet article a pour but de réfléchir sur les stratégies utilisées par les traducteurs lorsqu'ils traduisent les métaphores, le facteur qui reflète le mieux la différence socioculturelle entre deux pays. Nous nous sommes particulièrement intéressé à la traduction en coréen de textes écrits en russe. Le résultat de notre analyse montre qu'une bonne connaissance de la différence socioculturelle de la Russie et de la Corée est un élément primordial pour assurer la qualité de la traduction et pour surmonter les limites de la traduction coréenrusse, relativement récente en Corée.

\begin{abstract}
Translation is an act of communication across dissimilar cultures as well as a dynamic activity in which translators are required to make choices and decisions for the purpose of resolving problems. This paper draws on metaphoric expressions and their translations to recapitulate that the work of translation is not limited to the languages or the texts involved but is a dynamic activity that bridges two diverse cultures. Metaphoric expressions are non-literal, have implied meanings, and are used to emphasize a point or to enhance the expression's impressibility. Furthermore, metaphoric expressions are affected greatly by the culture to which they belong because they are created through a complex interaction between object, image, and sense. Consequently, in order to properly communicate the true meanings of these metaphoric expressions, translators play the role of an active mediator by either replacing the metaphoric expression found in ST with a different but compatible metaphoric expression or by using non-metaphoric, descriptive expressions or by appending additional explanation. This paper uses Korean translations of metaphoric expressions found in Russian source texts as examples to discuss the socio-cultural differences between the two cultures, how these characteristics are revealed in Russian-Korean translations, and how these issues are overcome. Based on the research results, the paper also emphasizes that understanding the vastly different sociocultural characteristics of these two cultures is essential to the field of Russian-Korean translation with its relatively short history, to not only improve the quality of translations but also for the field's continual advancements.
\end{abstract}

\section{초록}

번역은 상이한 문화권 사이의 의사소통 활동이자 문제의 해결을 위해 번역사의 선 택과 결정을 요구하는 역동적인 활동이다. 본 논문은 번역이 단순히 언어 대 언어, 텍스트 대 텍스트의 관계에 국한되는 것이 아니라 상이한 문화권을 중개하는 역동 적인 활동이라는 것을 은유적 표현의 번역을 통해 확인해보고자 한다. 은유적 표현 은 비문자적이고 함축적인 의미를 가지며, 말하고자 하는 바를 강조하거나 표현력 을 향상시키는 기능을 한다. 그리고, 표현하고자 하는 대상과 이미지, 센스사이의 상호작용을 통해 복합적으로 만들어지기 때문에 해당 문화권의 영향을 많이 받는 다. 따라서, 이러한 은유적 표현이 가지는 의미를 제대로 전달하기 위해서 번역사 는 ST 은유적 표현을 상응하는 의미를 가지는 다른 은유적 표현으로 바꾸어주거나 은유적인 특성을 가지지 않는 기술적인 표현으로 바꾸어주거나 부가적인 설명을 
덧붙이는 등의 적극적인 중개노력을 기울이게 된다. 본 논문에서는 러시아어 원문 텍스트에 포함되어 있는 은유적 표현이 한국어로 번역된 예들을 통해서 양 문화권 사이에 어떠한 사회-문화적 차이가 있으며, 노-한 번역에서 이러한 특성들이 어떻 게 나타나는지, 그리고 어떻게 극복되는지를 살펴보고자 한다. 그리고, 이러한 분 석 결과를 토대로 상대적으로 그 역사가 짧은 노-한 번역이 그 번역의 질을 높이 고 계속적으로 발전을 하기 위해서는 이러한 상이한 사회-문화적 특성에 대한 이 해가 필수적이라는 사실을 강조하고자 한다.

\section{MOTS-CLÉS/KEYWORDS}

metaphoric expression, culture, literal meaning, implicit meaning, translator training

\section{Introduction}

It has already been firmly established by many translation theorists that the act of translating is inevitably influenced by the society and the culture of the source text (ST) and the target text (TT). In addition, translation theories have gone through a major transformation in the 1980's towards intercultural and interdisciplinary researches from the conventional comparative - and contrastive - linguistics of the 1960 's and the 70's, which mainly focused on the comparative analysis of language structures or expressions. Bassnet-Mcguire has stated, "translation plays the role of filling in the gap between a wide range of disciplines such as language, literature, history, linguistics, symbolism, and aesthetics" (Bassnet-Mcguire, [1980] 1991: 6). This indicates that translation researches are not limited simply to the analysis of the text at hand but can explain the diverse nature of the society and the culture to which the text belongs. This research analyzes Russian ST and Korean TT to examine the social and cultural differences between Russia and Korea, how these differences are expressed in translations, and what strategies are used to overcome these issues. The objects of the analysis are words and expressions that are used not by their original, literal and fundamental meanings but have been attributed with special cultural senses for having been used in the corresponding society and culture for a given period of time and include vocabulary, idioms, proverbs, etc. that are generally regarded as broad metaphors $^{1}$ or metaphoric expressions. Texts used in the analysis are composed of Russian texts on politics ${ }^{2}$ and Korean translations of these texts. The reason for selecting political texts is that metaphors are generated very actively in political passages, and various metaphoric expressions are used deliberately in political passages to raise their quality and persuasive power. Since addresses and statements of politicians are influenced more heavily by the culture than any other political texts (Shaffner, 1997), the present research mainly utilizes political addresses and interviews for the purpose of observing how socio-cultural characteristics are revealed and resolved in metaphor translations. Prior to discussing the detailed analysis of socio-cultural characteristics found in ST and TT, there is a need to first define what metaphor is and the characteristics it possesses and what 'culture' constitutes and the role it plays in metaphor translations.

\section{Metaphor, Culture and Translation}

The Webster dictionary defines metaphor as 'a figure of speech in which a word or phrase denoting one kind of object or action is used in place of another to suggest a 
likeness or analogy between them' (Song, 2000: 37). Since there are various opinions on the definition of metaphor and what constitutes its structural elements, it is a fact that the term has not been standardized. In order to avoid confusion, this paper uses the term as defined by the translation scholar Newmark and refers to the definition of other scholars as necessary. In metaphor, the object of the metaphoric expression is refered to as the object, the object of comparison as the image, and the basis on which the object and the image are connected or the meaning the metaphoric expression as the sense (Newark, 1988: 105). ${ }^{3}$ For example, in the statement, "she is a pig," 'she' is the object, 'pig' the subject, and 'dirtiness' or 'glutton' is the sense, a meaning derived from comparing 'she' to a 'pig.'

Metaphor is divided into the following according its metaphoric degree: dead metaphor, which is considered to have lost its metaphoric quality completely; frozen metaphor; highly conventional metaphor; live metaphor, which is considered as a creative expression of a writer; and inactive metaphor.

Metaphor is typically used in poems because most poetic languages deal with contrast and symbolism, but newspaper articles and presidential addresses, which seem to use the most standardized literal meanings of terms, also include a significant number of metaphoric expressions.

Inauguration speech of the formal U.S. President, Lyndon B. Johnson, on January 21, 1963

"...uncrossed desert and unclimbed ridge... the star is not reached and the harvest that's sleeping in the unplowed ground..."

Inauguration speech of the formal Korean President, Dae Jung Kim, on February 25, 1998

"All of us are being asked of our sweats and tears at the present time.

You need to help me this year when our nation is standing at the edge of a cliff.

The venture industry is the flower ${ }^{4}$ of the new century."

Inauguration speech of the current Korean President, Moo Hyun Roh, on March 5, 2004

"Korea is the bridge that connects China with Japan and the land with the sea.

The paths in the sky, the sea and the land are all open.

Revolution is the electric power ${ }^{5}$ for growth and integration is the steppingstone for take-off."

As seen above, metaphors do not use the literal meaning but assume an applied meaning, and the applied meaning is more often than not signified differently across cultures. Nida and Taber (1969: 107) point out that the word 'heart' does not carry the same applied meaning in Africa as it does in the western culture, so 'liver' must be used instead when translating into an African language. In the same manner, when translating the French phrase, 'Il a une mémoire d'éléphant.' (To have the memory of an elephant) into Korean, the object 'elephant' does not carry the same applied meaning of having a good memory in Korean as it does in French, so the expression must be paraphrased as 'having a good memory' when translated into Korean. Kussmaul (1995: 65) points out that the greater the distance between ST and TT's cultures, the more frequently cultural problems with metaphoric translations occur. For example, dragon represents good luck in China but evil in the western culture. Kussamaul (1995: 65) also indicates that religion and mythology play an important role in forming these symbolic and metaphoric meanings, and summarizes the strategies for 
translating metaphors, which can be said to imply the particular culture, into drop, replacement and explicitation, while emphasizing that there is no definite rule for choosing one of these three strategies over the others.

We can drop the cultural allusions or references, we can replace them with target culture material and we can also make implied information more explicit. Unfortunately, at a practical level there are no hard and fast rules available for the translator to guide him or her as to which of these three strategies should be adopted in individual cases. The key thing is therefore that when confronted with a problem case, we should decide what the appropriate strategy should be and that the decision arrived at should be governed by the more far-reaching considerations of text function within situation within culture. (Kussmaul, 1995: 72).

Snell-Hornby ([1988] 1995: 56) also zooms in on metaphor translation as a cultural issue in translation. Snell-Hornby emphasizes that metaphor is not made up of just one text or word. She says that metaphors are problematic in translation because different cultures and languages have different ways of conceptualizing and creating symbols, and thus, metaphoric meanings are particular to each culture. For example, in the English phrase, 'she is a cat,' the cat is used in the sense that she is malicious or spiteful. However, in German, 'katz' has the metaphoric meaning of grace and agility; therefore, translating the English phrase directly into German does not preserve the true meaning of the English metaphoric expression. Snell-Horny points out that "a metaphor is a complex of three dimensions (object, image and sense), reflecting the tension between resemblance and disparity."

The culture referred to here is not the deliberate culture of artistic activities reflected in performing arts but denotes every aspect of the socially regulated human life from the anthropological point of view (Hymes, 1964). In other words, it represents the objective of people's behavior and everything people need to know, recognize and feel in order to discern the social positions they can expect through their behaviors and to behave in the manner expected by the society to which they belong. The essence of Gohring's definition of culture is the following:

- The concept of culture as totality of knowledge, proficiency and perception

- Its immediate connection with behavior (or action) and event

- Its dependence on expectations and norms, whether those of social behavior or those accepted in language usage (Trosborg 1997: 146)

Kussmaul (1997: 69) also emphasizes the "importance of culture through factual knowledge and behavioral knowledge" based on the above definition. He proposes the importance of culture, cultural norms and traditions as behavioral knowledge crucial for training translation abilities and stresses the importance of this knowledge in translation of texts. Moreover, a translation that does not practice the cultural customs and traditions of the TT culture as well as the ST culture cannot be called a successful translation.

As previously mentioned, Russian ST and Korean TT are the objects of analysis in this research. Russian-Korean translations have mostly been in the area of literature, and before scholars who majored in both Russian and literature began translation work, some Korean translations of Russian writings came through the Japanese translations of these Russian writings. Translations of the non-literary genre, including the political texts analyzed in this research, began actively in the 1990's when Korea and 
Russia formed amity. Consequently, not much research has been done on Korean translations of Russian works compared to other languages, and almost no attempts have been made in the area of analogizing the difference between Korean and Russian cultures based on the analysis of translations. The following chapter deals with the concrete differences found between Korean and Russian cultures based on the analysis of how Russian metaphors containing culturally implied meanings are translated into Korean, and how these differences are overcome in translations.

\section{Analysis of Russian-Korean Translation}

The example sentences analyzed in this chapter are from President Putin's biography and the Russian freedom party leader, Zhirinovsky's addresses ${ }^{6}$.

ST: А политика - это сливки экономики. Значит, в экономике мы отстаем в 50 pa3.

Literal Translation: Politics is the cream of economy. In other words, our economy is about 50 times behind.

$\mathrm{TT}$ : 정치는 경제의 노른자위이다. 그것은 경제에서는 우리가 50 배나 뒤져있다는 것을 의미한다.

(Politics is the egg yolk of economy. This means our economy is about 50 times behind ${ }^{7}$.)

'Сливки' is a Russian word meaning cream. 'Сливки' refers to the cream formed at the mouth of a bottle when cow's milk is gathered and stored for a period of time using the conventional method. It is a high quality food that used to be enjoyed exclusively by the nobility and the upper class because it was extremely small in quantity and believed to contain the condensed substance of all of milk's nutrients. The word reflects the culture's main diet of milk and bread and the culinary lifestyle centered on dairy products, and its implied meaning of being small in quantity and high in quality is currently used in its metaphoric sense to signify the society's 'essence' or 'elite.' 'Cream' in English and 'crème' in French also have similar metaphoric meanings. It is a common metaphor found in the western culture where milk and bread is the main staple but needs to be replaced with a different word when translating into an Asian language.

Before stating the aforementioned sentence, the author of ST makes a note of the fact that Russia is 10 times behind the rest of the world in politics. The author uses 'сливки' the metaphor in 'politics is the cream of economy' to emphasize that if the essence is 10 times behind then the rest must be about 50 times behind. This type of metaphor reflects the entire European as well as the Russian eating culture; therefore, a translator responsible for translating these concepts into a language of another culture that does not share the same customs must not only understand the word's true meaning but also make even greater efforts to find a similar expression in TT. 'Cream' is not a common word in Korean as it is in Russian and is not usually used as a metaphor, so the translator expressed ST's metaphoric meaning of 'essential part' as 'egg yolk.'

ST И глупо говорить: нет, я буду семечками торговать.

Literal Translation: I cannot say 'I will sell seeds.'

TT: 저는 길에서 포장마차나 할 겁니다라고 할 수는 없지 않습니까.

(I cannot say 'I will be a street vendor.' ${ }^{\text {) }}$ ) 
The example above is related to the time when Putin was appointed as Yeltsin's successor. He could not decline the position but neither did he feel pleased about the appointment. Putin repeatedly articulated his reluctance to having been appointed as the successor and expressed his inability to suddenly quit politics and assume the life of a commoner as not being able to say, 'I will sell seeds.'

It is a familiar sight in Russia to find people on the streets with seeds, like sunflower seeds in their hands. The easiest thing for people with no ability or experience to earn money is selling seeds of homegrown fruits or plants on the streets. 'To sell fruit seeds' found in the example sentence is used as a metaphor to mean the type of work so common that anyone can and in most cases, that commoners do. However, selling fruit seeds in Korea does not have the same implied meaning of 'a type of commoner's work that anyone can do.' This is an obvious outcome due to the different lifestyles found in Russia and Korea. A literal translation does not deliver the true meaning of ST. The translator used 'street vendor', the metaphoric expression of the TT society, which is Korea in this case, to represent the common work done by the lower class.

ST: Действовали как бы из-за угла, чтобы не торчали уши...

Literal Translation: It was to hide the ears.

TT: 쥐도 새도 모르게 일을 처리하기 위해서였습니다.

(It was to handle the matter without the mouse and the bird's knowledge. ${ }^{9}$ )

The above sentence is a metaphoric expression found in a Russian folktale. The metaphor comes from a folktale about "a wolf in sheep's clothing" that disguised itself to steal sheep but was caught because its ears were showing. To show one's ears means having of one's secret or identity discovered. There exist many metaphors derived from folktales in Russia because Russian folktales and proverbs are interwoven throughout the lives of many Russians. The translator expressed 'in secret' through a Korean idiom, 'without the mouse and the bird's knowledge.'

ST: Но, показать уши считалось неприличным.

Literal Translation: It was not recommended to show the ears.

$\mathrm{TT}$ : 드러낸다는 건 바람직하지 않던 시절이었습니다.

(It was a time when revealing one's identity was not recommended.)

The above sentence is found in the same folktale. Although it has the same meaning, the translator changed it to a more descriptive expression, 'revealing one's identity.'

ST: Сегодня самое страшное - это снова делить людей по политическим признакам: красные-некрасные, коричневые-белые.

Literal Translation: The scariest thing today is categorizing human beings into red, nonred, brown and white for political purposes.

TT: 오늘날 가장 무서운 일은 인간을 정치적인 이유로 공산주의자와 비공산주의 자, 변절자, 반동 등으로 또다시 구분하는 것이다.

(The scariest thing today is categorizing human beings into communists, anti-communists, traitors, and recoil for political purposes.)

The example above deals with color metaphors. Morgan says, "Comparative expressions dealing with colors vary greatly just as much as they are shared by different cultures"(Morgan 1993: 131). The colors in this example are red, white and brown. Red universally represents communism. In contrast, non-red naturally represents 
anti-communism. Brown and white carry special meanings in political passages according to Russia's historical background. German Fascists wore brown uniforms before World War II, and thus, are referred to as the 'brown' people. White is one of the three colors that traditionally represented the Czar, namely red, gold and white, and only the nobility and the high-class people were allowed to wear white-colored clothing. On this basis, white signifies the royalists and the monarchists. In addition, the soldiers who fought against the troops of the communist regime and protected the royal families during the Russian revolution is referred to as the 'white army', and thus, the color white has the added meaning of 'recoil,' or opposing communism.

In the example sentence, the translator uses non-metaphoric expressions, 'communists, anti-communists, traitors, and recoil' to represent the color metaphors of ST. Although it may belong to the family of red, brown is not entirely red and neither is it any other color; hence, it would have been more appropriate to translate brown as 'Fascists' and not as 'traitors,' since the text uses philosophical and political backgrounds as criteria for categorizing people into groups.

ST: Если черные стрелы Барбаросса и майн-камфа прочерчивались на Россию с запада, то зеленые стрелы фанатиков ислама тянутся с юга на север по Волге до Татарстана.

Literal Translation: If the black arrow of 'Mein Kampf' and Barbaross is said to have come to Russia from the west, then the blue arrow of the Islamic activists is flying from the south to the north, through the Volga River, to Tatarstan.

TT: 마인 캄프(히틀러의 저서 ‘나의 투쟁’으로 여기서는 히틀러를 뜻함)와 바르바 로스(히틀러의 대소작전 암호명으로 ‘붉은 작전’이라는 뜻)의 검은 화살이 서쪽 에서 러시아에 날아왔다면, 이슬람 광신도들의 푸른 화살은 남쪽에서 북쪽으로 볼가강을 따라 타타르스탄까지 날아오고 있다.

(If the black arrow of 'Mein Kampf' (a book written by Hitler and signifies 'Hitler' in this context) and Barbaross (a secret codeword for Hitler's anti-Russian strategies and means 'red tactics') is said to have come to Russia from the west, then the blue arrow of the Islamic activists is flying from the south to the north, through the Volga River, to Tatarstan.)

The victory against the Nazis in World War II has a great historical significance among Russians because it saved not only Russia but also the entire Europe. Consequently, Hitler's book, Mein Kampf, and Barbaross, the Germans' strategies for invading Russia during World War II, symbolize the German Nazis and at the same time metaphorically represent Nazism of Germany to the Russian people. In TT, the metaphoric expressions signifying these historical backgrounds are clarified to the TT readers by providing explicit explanations marked by parenthetical notations.

As Kussmaul (1995: 65) points out, the greater the distance between cultures, the greater the difference in biblical stories and myths; consequently, metaphors originating from biblical stories and myths and their socio-cultural characteristics present challenges when translating into a language of a vastly different culture.

ST: Чтобы призвать куправлению государством и обществом лучших государственных мужей, нужны политические партии внутри которых разные будут смеси и коктейли, но все-таки появится плеяда людей, среди которых можно будет когото выбирать.

Literal translation: In order to bring in people who are great for the government and talented in politic, it is necessary to have a political party with Pleiad even if it has a countless number of hodgepodge mixtures. 
TT: 국정에, 사회통치에 훌륭한 사람들을 불러들이기 위해서는 그 내부에 수많은 잡탕, 혼합물이 있지만 그 와중에도 선택할 만한 기라성 같은 인물들이 나타날 정 당이 필요하다.

(In order to bring in superb government administration personnel, there is a need for a political party with a core group of great people even if it has a countless number of hodgepodge mixtures.)

'Плеяда' (Pleiad) refers to the seven daughters of Atlas in the Greek mythology. The word's original meaning has been expanded to possess the metaphoric meaning of 'a group of great people.' Although interest in the Greek language and mythology has declined over time, the Greek language has had a significant influence on the Russian society and was even a required subject in schools until the $19^{\text {th }}$ century. The historical accounts of the time period from Greece to Rome play an extremely important role in Russia and all of Europe. Consequently, there are many Russian terms related to Greek mythology and to historical accounts of the time period from Greece to Rome.

The following are examples of words that have their origin in the Greek mythology and are used as metaphors in political texts.

Конституционная система власти не вмещается в прокрустово ложе исполнительной вертикали. (Российская газета, 22.02.2004)

The composition of a nation's constitution does not meddle with the Procrustean bed of the executive administration.

Многопартийность - сизифов труд: что ошибочно? (press21.ru, 24.04.2002)

Multiparty system - labor of Sisyphus: what went wrong?

As seen in the above examples, Russian has many metaphoric expressions based on Greek mythology. These metaphors cannot be preserved during translation into another language that does not share the same mythological background but must be transformed. For example, an expression, 'a core group of people,' is used in the Korean translation to overcome the gap created by mythological differences.

All of the examples mentioned in this paper are metaphoric expressions used not by their literal meanings and portray the Russian socio-cultural characteristics that are different from their Korean counterparts. 'Cream' reflects the economic activity, eating habits and the western culture based on stock farming, and the metaphoric expression, 'to sell seeds,' signifies the lifestyle of the low class trapped in dire social and economic circumstances. The translator changed these metaphoric expressions into 'egg yolk' and 'to work as a street vendor' respectively to preserve and reflect the true cultural meanings when translated into Korean.

It has also been confirmed that Russia's traditional proverbs and folktales are embodied in metaphoric expressions. Such metaphoric expressions as 'to hide one's ears' and 'to show one's ears' are based on the Russian folktale, 'Wolf in sheep's clothing,' and are translated into Korean through an idiomatic expression, 'without the mouse and the bird's knowledge,' and a paraphrase, 'to reveal (one's identity),' respectively. In other words, in order to communicate the meanings of metaphoric expressions originating from Russian proverbs into Korean, a language that does not share the same proverbial background, the translator chose the methods of using an idiomatic expression with similar characteristics and of replacing the expression with a paraphrase.

The Korean translations of Russian metaphoric expressions derived from Russia's traditional social and historical backgrounds demonstrate that changing the structure 
of ST's metaphoric expressions is inevitable in some cases. 'Red, non-red, brown and white' is translated as 'communists, anti-communists, traitors, and recoil' and 'the black arrow of Barbaross and Mein Kampf' is explained as Hitler's book and antiRussian strategies respectively through added parenthetical notations. Furthermore, metaphoric expressions derived from Greek mythology are replaced by other nonmythological words when translated into Korean because the Korean language is not as deeply rooted in myths as Russian is. The analysis of the aforementioned examples confirms that differences in lifestyles, proverbs, socio-historical backgrounds and myths are demonstrated in Russian-Korean translations.

\section{Conclusion}

Socio-cultural characteristics can be said to be one of the typical translation problems a translator must resolve in translation - an activity of communication between different cultures. Based on the analysis of various metaphoric expressions found in Russian political passages and their Korean translations, socio-cultural characteristics found in translation can largely be divided into four areas: lifestyle, proverb, sociohistorical background and myth. The analysis also indicates that these differences in socio-cultural characteristics can be overcome by replacing ST with a different descriptive expression or a similar metaphoric expression or by adding supplementary explanations.

The socio-cultural characteristics found in translation are of important significance in teaching translation as well. This is because these socio-cultural characteristics require a more active mediation by the translator, since the true meaning of the ST expressions cannot be delivered to the TT readers if translated literally. Research on socio-cultural characteristics also reveals that translation does not simply connect a language with another language or a text with another text, but creates a dynamic relationship between various entities of writers and readers, including the ST writers and readers and the TT writers and readers. As mentioned previously, the history of translation between Russian and Korean is short compared to other languages, and there has been little research in this area. Korea's interests in Russia have been actively played out in many academic disciplines including literature, language studies and regional studies but not in translation studies. Cultural research based on translation is expected to flourish through much future research.

\section{NOTES}

1. YoungSoon Park regulates the language usage for the research as follows:

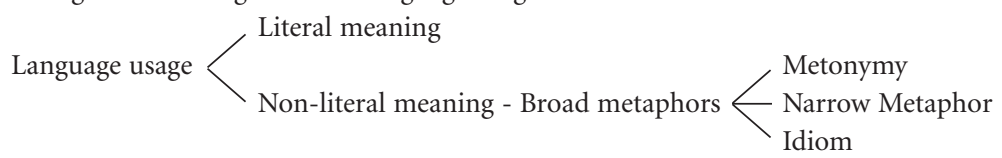

(Park, 2000: 67).

2. Political text is a vague word and covers a wide-range of concepts such as varied text styles and genres. Political discourses consist of both the intrastate and interstate conversations and have diverse structures. For example, they include such passages as bilateral treaties, addresses used in political campaigns or at political party conventions, congressmen's assembly defenses, newspaper natives or columns, press conferences of political personnel, memoirs, etc. (Shaffner, 1997). 
3. According to Richards, who contributed tremendously in the area of metaphor research, the terms are referred to as topic (or tenor), vehicle and ground respectively (Richards, 1936).

4. 'shining star' in English.

5. 'launch pad' in English.

6. Zhirinovsky (1993). Russia's Fate: The Last March to the South. Translated by MyungHo Kim. Seoul: HanWool.

Geborkian, Timakova, Kolesnikov (Eds.). (2000). Biography of Putin. Translated by YoonKyung Pyo. Seoul: Literature Ideology Co.

7. 'Politics is the essence of economy. This implies that our economy is about 50 times behind the rest of the world.'

8. I cannot say 'I will go flip burgers.'

9. It was to handle the matter in secret.

\section{REFERENCES}

BAssnett-Mcguire, S. ([1980] 1991): Translation Studies, London, Routledge.

Chог, J.W. (2003): “Interpreting Competence and Cultural Differences," Forum 1-1, p. 97-111.

Goatly, A. (1997): Language of Metaphors, New York, Routledge.

Hymes, D. (1964): Language in Culture and Society: A Reader in Linguistics and Anthropology, New York, Harper and Row.

Kussmaul, P.(1995): Training the Translator, Amsterdam and Philadelphia, John Benjamins.

(1997): “Text Type Conventions and Translating: Some Methodological Issues," In A. Trosborg

(Ed.), Text Typology and Translation, Amsterdam and Philadelphia, John Benjamins.

Larson, M.L. (1984): Meaning-based Translation: A Guide to Cross-language Equivalence, Lanham, University Press of America.

Leppinalme, R. (1997): Culture Bumps - An Empirical Approach to the Translation of Allusions, Clevedon, Multilingual Matters.

Morgan, J. L. (1993): “Observations on the Pragmatics of Metaphor," In A. Ortony (Ed.), Metaphor and Thought, New York, Cambridge University Press.

Newmark, P.(1988): A Textbook of Translation, London, Prentice Hall.

NidA, E. and C. R. TABer (1964): Toward a Science of Translating: With Special Reference to Principles and Procedures Involved in Bible, Leiden, E.J. Brill.

Nord, C.(1997): Translating as a Purposeful Activity: Functionalist Approaches Explained, Manchester, St. Jerome.

PARK, Y.S. (2000): The Problem of Metaphor in Korean Language, Seoul, Korea University Press.

Richards, I. A. (1936): The Philosophy of Rhetoric, London, Oxford University Press.

Snell-Hornby, M.([1988] 1995): Translation Studies: An Integrated Approach, Amsterdam and Philadelphia, John Benjamins.

Shäffner, C. (1997): Strategies of Translating Political Texts, In A. Trosborg (Ed.), Text Typology and Translation, Amsterdam/Philadelphia, John Benjamins.

Song, K.S. (2000): Metaphor and Metonymy in Korean and American Political Discourse, Discourse and Cognizance 7-1, p. 35-61.

Trosborg, A. (1997): Text Typology and Translation. Amsterdam/Philadelphia, John Benjamins. 